\title{
Municipalities and educational modernisation: a historical and geographical atlas of municipalities and education in Portugal
}

\section{Justino Magalhães}

To cite this article: Justino Magalhães (2017) Municipalities and educational modernisation: a historical and geographical atlas of municipalities and education in Portugal, Paedagogica Historica, 53:5, 578-601, DOI: 10.1080/00309230.2017.1297470

To link to this article: https://doi.org/10.1080/00309230.2017.1297470

曲 Published online: 11 Apr 2017.

Submit your article to this journal $₫$

山 Article views: 50

Q View related articles $\sqsubset$

View Crossmark data $\nearrow$ 


\title{
Municipalities and educational modernisation: a historical and geographical atlas of municipalities and education in Portugal
}

\author{
Justino Magalhães \\ Instituto de Educação, Universidade de Lisboa, Lisbon, Portugal
}

\begin{abstract}
This text focuses on municipalities from an educational and cultural perspective. Over the last 200 years, municipalities have played a fundamental role in the creation of guiding principles and educational norms and conventions. They have participated in the supply and universalisation of schooling and have contributed to integrating the public sphere and the modern, contemporary political structure. Municipalities as territories, populations, economies, and collective governments backed by written administration have influenced and become the model of the liberal and republican political and educational transformations. They have been crucial to the political, administrative, and socio-cultural constitution of the contemporary state. The school institution has integrated social and political development while educational modernity has brought school cartography closer to demographic, administrative, and cultural cartography. The municipal initiative has played a key role in terms of territorial suitability, modernisation of the school network, and curricular diversity. This text picks up on the main conclusions of the Educational and Cultural Atlas of the Municipalities in Portugal, and places the Portuguese context within a European and western framework. Municipalities are presented as an educational space, with historical and pedagogical importance in the modernisation of schooling, despite a historiographical tendency to dilute them into the state, connecting them to an official perspective of education. The article contains a summary of the Educational Atlas of the Municipalities in Portugal.
\end{abstract}

\section{ARTICLE HISTORY}

Received 16 November 2015 Accepted 24 January 2017

\section{KEYWORDS}

Educational modernisation; municipality; pedagogical municipality; historical and geographical atlas

\section{The municipality as a local educational establishment}

Over the last two centuries, educational schooling has served as a means of universalising standards of civilisation and modelling cultural references, adjusting traditions and customs; standardising behaviours and languages; determining policies; normalising institutions; and disciplining organisations. Written acculturation has approximated 
the universal, transnational, national, and local, enabling these different bodies to apply the same measures to the processes of recording, assessing, and governing. Pedagogical writing has standardised terminology and communication with regards to nominating, measuring, comparing, and ordering. Since the mid-twentieth century, the globalisation of educational schooling has advanced rapidly and irreversibly, with the support of UNESCO and other international organisations and confederations, namely the International Monetary Fund (IMF) and the Organisation for Economic Cooperation and Development (OECD). Over time, the abstract and standardising nature of globalisation boosted the development of the educational, substantive, concretive, intelligible, and comparable municipality.

The municipality, as a local denomination, power, and representation, has always been a part of the public sphere and the construction of modern western states, and over the last few decades it has taken on a new contemporariness as an educational space. ${ }^{1}$ The acknowledgement of cultural diversity, the attribution of meaning to education, and school accreditation have all occurred at the local level, as an integrated pedagogical complex, or as a complement or adjustment to the curriculum. The standardisation of educational conventions and the universalisation of the school model have enhanced autonomy on a local scale. The municipality, local institution and territory, became a sovereign entity in decision-making. Consequently, the singularity of the municipality emerged as metaeducation, a transfer, conversion, and complement. It has played a key role in the universalisation of school literacy. Once the basic core curriculum had been established, educational systems and communities engaged in initiatives and policies to complement and adapt the supply of schooling to economies and socio-cultures, by means of alternative programmes adapted to the territories, circumstances, and conveniences of communities and groups. Its autonomous context endowed the municipality with uniqueness and stripped meaning from interpretations of the municipality as a miniature of the global or national. In the hierarchy of educational territories, and among municipal bodies, the municipal initiative in Portugal contributed to a territorialisation of the school network, a pedagogical alternative, professional and vocational training, and, ultimately, to the universalisation and continuation of schooling.

Taking the relationship between the school and society as the driving force behind development, and the central, local power binomial as substance and change, historiography has presented western educational modernisation as a nation-state plan. The alignment and sequential order of this lengthy state process are associated with the centralisation of historical documentation. The documentation preserved in the central archives has given rise to and recorded a linear memory, lacking form only in its quality and intensity. It is here that historiography finds the grounds for official historicism. Furthermore, the lack of documentation on educational municipalities has been interpreted as a discontinuity or a reference to small-scale events. However, in the memories of education, in the municipal archives, and in the archives of school institutions, information shedding light upon and

\footnotetext{
${ }^{1}$ There is no room here to present a brief history of the Portuguese municipalities. In another study, I make reference to their administrative and autonomous status, within the context of the sovereign ordinances and the administration of the Atlantic empire. See Justino Magalhães, "As a Text: Configurations of Colonial Municipality Writing," História: Questões \& Debates 60, no. 1 (January-June 2014): 65-83, doi: http://dx.doi.org/10.5380/his.v60i1, http://ojs.c3sl.ufpr.br/ojs2/index. $\mathrm{php} / \mathrm{historia/issue/view/1802.}$
} 
suggesting other memories may be encountered, thus making it possible to reconstruct the municipal history of education. The municipalities were a part of this memory. ${ }^{2}$

In this regard, the Portuguese Municipal Archives have preserved documentation, enabling one to understand the historical silences and discontinuities of such local contexts, their integration in general history, and their singularities. They also make it possible to retrieve other memories and construct a history of municipalism in education. In the national memory of education, all that is local densifies, illustrates, or merely diversifies. However, the linearity of state policies and the controversies of the municipality are one and the same modernity. In contrast to the alignment and sequential order of the lengthy state process, local-scale education, namely through the municipality, was unstable and subject to breaches, ruptures, and oblivion. Education as a principle was established at the local level but remained subject to controversy, irregularities, and information gaps. A reconstruction of the local is not deduction, a critical summation of advances, ruptures, or retreats which historiography seeks to indirectly retrieve, nor is it a ramification of national history. The ordered records of educational memory also report on the local as an entity in itself.

The generalised implementation of writing in administrative modernisation and in manifestations of sociability triggered the municipalities, as collective and local governments of lettered justice, to foster and normalise handwriting. In fact, from the late seventeenth century, some counties already had primary schoolmasters who had been paid by city hall funds. By order of the Foral (Foral Charter), which instituted the county as a legal and administrative entity and established governmental rules, counties were granted the prerogative of establishing norms and conventions through the Posturas (document containing a set of legal guidelines). The counties prescribed their Posturas, which, as a local government instrument, contained a defining dimension of education, establishing usage, rules, rights, and duties. The counties were regulated by councillors, higher officials (judges and administrators), administrative officials (clerks, topographers and archivers, inspectors, caretakers), and also specialised officials, namely doctors and teachers, in turn, registered as employees or consignors. Sovereignty and officiality were the pillars of the administrative, social, pedagogical, and cultural municipality. The field of education promoted the municipalities as a public sphere. Some counties indexed their primary school education expenditure to the Cabeção das Sisas tax. The involvement of the nation-state in education instituted municipalities as territorial schooling units and communities took recourse to the county powers as a representation of central government.

At the time of the Pombal administration reforms, which were at the root of the Portuguese school proto-system and paid for by the public purse through the Subsidio Literário (Literary Subsidy) funds, the municipality was the main territorial schooling unit and constituted a socio-political representation. It was an entity of denomination, bookkeeping, and the allocation of resources, and within the Pombal administration and Queen Maria I context, it became a means and force of vindication and a promoter of education. With the liberal revolution, it was responsible for: the organising the census of school-age

\footnotetext{
${ }^{2}$ For a history of education on a local scale in France, see: Gérard Bodé and Philippe Savoie, eds., "L'offre locale d'enseignement. Les formations techniques et intermédiaires XIXe-XXe siècles," Histoire de l'Education 66 (May 1995). In the Introduction, the editors draw attention to the fact that "l'attention trop exclusive portée à l'action de l'État a conduit longtemps à négliger - jusqu'à la passer par pertes et profits - la réalité qui n'était pas éclairée par les polémiques nationales, les débats parlementaires et les lois" (7).
} 
children; guaranteeing schooling; promoting its demand and controlling attendance; and stimulating school literacy through commissions established to promote schooling and culture.

Regard for schooling and the recognition of school qualifications as political participation and privileged access to the specialised labour market, spilling over into sociability and improved collective and individual lives, became associated with the planning of the school network; standardisation of teaching duties; pedagogical and didactic bookkeeping; and the creation and maintenance of local courses. Indeed, the sovereignty of the municipalities boosted philanthropy; the constitution of school legacies; and the establishment of an array of charities and fundraising events, particularly those committed to improving the material and social conditions of access to schooling. The municipalities respected national law, however, their field of intervention varied from one municipality to another, not only in the nature of their actions but also in their levels of achievement. In the second half of the nineteenth century, the city hall of Lisbon created municipal schools which coexisted with state schools, private schools, and free (temporary) schools.

In the late nineteenth century, the assumptions of western schooling modernity were already structured and, on the whole, included: education through schooling; the universalisation and compulsoriness of primary schooling; subsidies shared among the state, private, and associative sectors; the integration and participation of the municipality in the supply of education; standardisation of the teaching profession; pedagogical school bookkeeping; and inspection as a means of regulation and control. This complex functioned through a system of which the municipalities were sub-systems. Education occurred at a local level, implying ideology, sovereignty, accomplishment, and participation. A record of the participation of municipalities in literacy and written acculturation has existed since the modern period, when they were responsible for schooling and acknowledged the validity of school qualifications as a factor of social and cultural promotion. From the second half of the twentieth century, the autonomy and sovereignty of the municipalities in education and schooling were definitively established in national and international agreements.

A sequence of historical and pedagogical cycles on schooling and its modernisation, transversal to the different states, will now be presented in terms of state control, nationalisation, government, regimentation, internationalisation, and diversification.

\section{Modernisation cycles of schooling}

From the eighteenth and nineteenth centuries, with the Protestant, Lutheran, Calvinist, and Catholic reformations, marked by the Council of Trent, the religious, political, and administrative authorities had begun to foster the establishment of small schools to catechise and teach literacy to children and adults. The geography of primary schools was connected to small religious (congregation or parish) or territorial (location, commune, villages, pueblo) units. In Britain, from the seventeenth century onwards, with the advancement of the vernacular, parish priests and tutors were urged to teach reading and writing. ${ }^{3}$ In France, the monastic and Presbyterian schools had been sufficient until 1542, when the Council of Trent prescribed the establishment of seminaries and ecclesiastical schools, admission to which was dependent on reading and writing correctly. Consequently, the synod authorities obliged

${ }^{3}$ See Joan Simon, Education and Society in Tudor England (Cambridge: Cambridge University Press, 1979) 376-7. 
the existence of and attendance at small schools. Accordingly, the king and the departmental authorities created legislation so that bookkeepers, magistrates, and other officials could set up small municipal schools. ${ }^{4}$ In Portugal, both the Cadeira de Primeiras Letras (primary school) and, at a later stage, the elementary school, were registered under the parish. These small schools were entrusted to social patron entities, philanthropy, individual initiative, schoolmasters and confraternities, congregations, local government entities, namely the councils, and were later affiliated to the central government, following the aforementioned Pombal administration reforms. Hence, the promotion of schooling remained open to private and confessional initiative, under a regime of complementarity.

In Spain, the small schools registered under localities and villages were documented by $E l$ Catastro del Marquês de la Ensenada, between 1750 and 1760. Following the Royal Order of 6 May 1760, inspectors and mayors were required to report on the absence of schoolmasters to teach reading, writing, and Latin in towns and villages. The municipalities and guilds intervened in the establishment of schools and in the training of schoolmasters. ${ }^{5}$ Until the end of the eighteenth century, most British, Belgian, and American primary schools were entrusted to the religious authorities, communes, and municipalities. By rule, in addition to same-sex state primary schools, municipalities and towns also had one or two schools for continued studies - grammar schools, complementary schools, and borough schools. The communes and municipalities were to be given free state education. The local authorities had organised pedagogical writing; entities and charity organisations; municipal schools; and courses for further education and technical and professional training. This is what occurred in most of the German dukedoms and grand duchies. In Saxe-Weimar Duchy, based on an eighteenth-century state law, it was expected "qu'il y ait dans tout village une maître d'école; et par ce mot de village (Dorf) on entend ici la plus petite réunion de familles". ${ }^{6}$ In France, the city (particularly a large city) was deemed privileged territory for the development of continued schooling. ${ }^{7}$

From the late eighteenth century, written acculturation included the vulgarisation of reading in order to comply with religious precepts and the dissemination of ideas, whether among Protestants or Catholics. Throughout the eighteenth century, handwriting became the object of collective education and bookkeeping was regarded as a modernisation factor of state administration, the sustenance of lettered justice, and the support of private economies. Administrative modernisation and the revolutionary context, which paved the way for the Declaration of the Rights of Man and of the Citizen, the transnationalisation of the Enlightenment, and material, scientific, and cultural progress, saw the school as a vehicle for the generalisation of demand and the standardisation of cognitive and behavioural knowledge. The constitution of the state and the religious public sphere is rooted in this confluence.

\footnotetext{
${ }^{4}$ See F. Buisson, ed., Nouveau Dictionnaire de Pédagogie et d'Instruction Primaire (Paris: Librairie Hachette et Cie, 1911), 1366; and Roger Chartier, Dominique Julia, and Marie-Madeleine Compère, L'Education en France du XVle au XVIIle siècle (Paris: Société d'Édition d'Enseignement Supérieur, 1976), 3-44.

${ }^{5}$ See Juan Manuel Fernández-Soria, "Município y Educación en España (centuries XIX-XX)" [Municipality and education in Spain (19th-20th centuries)], in História dos Municípios na Educação e na Cultura: incertezas de ontem, desafios de hoje [History of municipalities in education and culture: yesterday's uncertainties, today's challenges], ed. Áurea Adão and Justino Magalhães (Lisbon: Instituto de Educação da Universidade de Lisboa, 2013), 165-93, ebook accessible at http://www.ie.ulisboa.pt/portal/page?_pageid=406,1805117\&_dad=portal\&_schema=PORTAL.

${ }^{6}$ M.V. Cousin, De L'Instruction publique dans quelques Pays de l'Allemagne et particulièrement en Prusse, 3rd ed. (Paris: Pitois-Levrault et Cie Libraires, 1840), 32.

7Bodé and Savoie, "L'offre locale d'enseignement," 9.
} 
The Portuguese school proto-system, established after the Pombal administration reforms, became characterised by an overlapping of the state feature, formalised through a plan, which integrated, regulated, and expanded the already existing primary and grammar schools. The main cartographic unit was the county, however the classification included terminology of the era such as counties, landowners, and townships. Following the policies of Queen Maria I and King John VI, the aspect of county was taken as a reference. Statecontrolled primary education corresponded to an appropriation of the schooling cycle on the part of the state, through the school itself, with respect for and encouragement of singularities.

The denomination of locations and the school, and the standardisation of schooling, capitalising on its pedagogical transversality and potentialities for the education of individuals, underlie the comparative study launched by Marc-Antoine Jullien of Paris, Esquisse et vues préliminaires d'un ouvrage sur l'education comparée (Sketch and preliminary views of a book on comparative education), the printed version of which was published in 1817 . The study contained a rationality that brought together comparison and decision, providing pedagogy with a practical diagnostic instrument: the inquiry. After grounding the importance of education for "providing each individual with the profound feeling and practical knowledge of that which, in his sphere of activity, he should know, want and do", he presented a plan to gain knowledge of education in the 22 cantons of Switzerland and parts of Germany and Italy. $^{8}$ At a later stage, the inquiry was to be extended to all the European states.

The author knew that various governments had given instructions to observe the Institutes of Pestalozzi and Fellenberg, and he was convinced that "the universal tendency to attain the same objective, the regeneration and refinement of state education [...] was a clear indication of the common need of all governments and all peoples". 9 The plan proposed by Jullien de Paris to compare the educational reality of different countries was made up of six themes: (a) primary and common education; (b) secondary and classic education; (c) higher and scientific education; (d) normal education; (e) education for women; and (f) education in its relations with legislation and social institutions. ${ }^{10}$ These analytical summaries of data collected "at the same time and in the same order, on the situation of education and public schooling in every country in Europe", would provide comparative frameworks that would make it possible to assess which European nations were progressing and which were stagnant or reverting, in addition to understanding the causes, obstacles, and ways of overcoming them. ${ }^{11}$ Finally, they would enable an assessment of which subjects to take from one country to another.

Thus, by intersecting the national (nation state) and the local (municipalities), whether referring to Portugal or other western countries, it is possible to systematise a sequence of historical and pedagogical cycles of medium duration, beginning with the control of education and schooling by the state, hence marking its sovereignty. In Portugal, the Pombal administration reforms are what triggered this process. The immediate cycle was characterised by nationalisation, corresponding to a legitimisation of a state-run school with a standard curriculum representing national education. The schooling of culture, memory,

\footnotetext{
${ }^{8}$ Jullien de Paris, Esquisse et vues préliminaires d'un ouvrage sur l'education comparée/Esboço de uma obra sobre a Pedagogia Comparada (Lisbon: Instituto de Inovação Educacional, 1998). 9 lbid., 21.

${ }^{10}$ lbid., 31-3.

${ }^{11}$ Ibid., 21.
} 
and citizenship brought coherence to the liberal reforms and converted the school and school education into a homeland memory, a scientific encyclopaedia, and an artistic and literary canon. Throughout most of the West, including the United States of America and Brazil, the latter having just gained its independence in the mid-nineteenth century, the construction of nationalism was under way and the school represented rationality, linguistic, and civic standards, an environment of citizenship and patriotism. Liberalism brought a reconfiguration of the administrative maps, as was the case in Spain which saw the approval of the Cadiz Constitution in 1812. The municipalities' ayuntamientos were established as the territory and entity of reference in the supply of schooling. ${ }^{12}$ In Portugal, the liberal reforms of Terceira Island Governance (1831-34) regarded the municipality as the ruling entity and territory.

School territoriality underlies nineteenth-century reforms within the state and national scope. In Prussia, a law of 1819 stipulated the obligation to teach, for each village to have its school, including rural communes. In exceptional cases, two communes were permitted to partner in order to sustain the same primary school. State education was free. The French Second Republic became associated with the state education reforms that secured state school uniformity and entrusted the main role of promoting schooling to the municipal and regional entities. Within this framework, the political action of Guizot is worthy of mention, as he was responsible for the implementation of a national inquiry, conducted by the inspectors of the municipalities.

In Belgium, where the church had full authority over schooling, following the law of 23 September 1842, it was the responsibility of each commune to have a school, while it was also permitted for two communes to join forces to found and sustain a shared school. The communes were also responsible for primary schooling expenditure, which they were obliged to include in the yearly budget. Funds were allocated by the provinces and the state for the purchase of books for school libraries. Only exceptionally would they contribute financially towards the maintenance of these shared schools. The communal council would select and nominate the teachers. Inspection of primary schooling was conducted by provincial and cantonal inspectors and by delegates of educational leaders. The supply of schools included communal, private (boarding), and free schools. Whenever a private school that could meet the educational needs was in close proximity, the commune would be excused from having to establish a communal school. ${ }^{13}$

Analogously, in freed Italy, the law of 13 November 1859, relative to free primary education, was gradually implemented from Piedmont. Each commune was required to have

\footnotetext{
${ }^{12}$ El Catastro del Marquês de la Ensenada, established by the Royal Decree of 10 October 1749 and conducted between 1750 and 1760, was made up of a questionnaire of 40 questions, two of which referred to expenses of the municipality with officials and experts and the existence of specialised professionals. These questions gave rise to the inventory of schoolmasters of primary education and Latin. Based on the answers to these questions, it was possible to catalogue and, to a certain extent, to map the school network of Castile (see Jean-Louis Guereña and Antonio Viñao-Frago, Estadística Escolar, Proceso de Escolarización y Sistema Educativo Nacional en España (1750-1850) [School statistics, educational process and national educational system in Spain (1750-1850)] (Barcelona: EUB, 1996), 24-5). The Royal Decree of 6 May 1790 obliged the inspectors and mayors to provide information on the townships and locations which were lacking in "Escuelas de primeras letras y enseñanza", in addition to specifying the distance between locations and schools ("Aldeas o Caserías") (ibid., 33-4). The Constitution of 1812 recognised the entity of the municipality, maintaining the municipalities of the former regime and extending the denomination without distinguishing between "royal municipalities" and "Iordship municipalities". However, a standardisation process was already under way, taking the "ayuntamento municipalities" as a reference and 1000 inhabitants in each respective location as a criterion.

${ }^{13}$ For further information, see Joaquim Henriques Fradesso da Silveira, O Ensino Primário na Bélgica [Primary teaching in Belgium] (Lisbon: Imprensa Nacional, 1872).
} 
at least one primary school for boys and another for girls. At a certain stage of the year, they were required to serve as open schools in isolated communal areas where there were more than 50 children. In some circumstances, two communes were allowed to join forces to maintain a shared school. ${ }^{14}$ In the mid-nineteenth century, by combining school standardisation and linguistic and curricular nationalisation, the generalised movement of establishing state systems for primary education was in progress.

The nationalisation of school culture boosted the internationalisation of curricular standards and school literacy, suited, albeit, to each vernacular language, related to furniture, writing, scientific and technical observation instruments, quantification, production, measurement, and assessment. The internationalisation and modelling movement included holidays, exhibitions, and transnational agreements. ${ }^{15}$ Within the context of rapid industrialisation, the manufacture of school furniture and didactic materials was subject to competition between national and foreign manufacturers. The school book affirmed itself as an autonomous editorial product, within a framework of high competitiveness, and benefited from the advances in typography, thus corresponding to didactic stylisation.

Pedagogical and didactic writings, largely the result of school inspection and the professionalisation of teachers, were mainly geared towards standardisation, with the use of forms and statistical data. The school institution contained pragmatics and protocols which guaranteed hierarchy and functionality, through standard forms, formulae, measurement, comparison, and assessment. The municipalities, as territories and administrative, cultural, and organisational entities, had their own schools and intervened in the process of hiring teachers. School inspection brought new responsibilities to the municipal authorities in terms of control and preparation of educational reforms. Such was the case in France, with the preparatory general inquiry established by the Guizot Law in 1833. In Britain, it was the duty of the inspectors nominated by the committee on education to draw up local reports. In Portugal, following the Costa Cabral Reform (1844) and later regulations, county administrators were required to visit schools and provide thorough reports to be sent to the civil governments and higher council of education.

The writing of school inspection is an important source for local history. Thus, the Inspections of 1863-4 and the Inquiry of 1875 are worthy of particular mention. Taken together, they form a vast printed archive presenting innovative features of pedagogical and didactic bookkeeping. The forms were designed by pedagogues who participated in the transnational standardisation process. Their application was entrusted to a body of duly prepared inspectors. They are entries organised into schools, composed of quantitative and qualitative items, with a space for comments regarding the school and each municipality as a set of schools.

From the early nineteenth century, the denomination and statistics of schools were regarded by the local municipality as a reference. By rule, the schools were given the names of the locations. The locations were characterised in terms of their administrative status, adult and school-aged population, supply, and performance.

\footnotetext{
${ }^{14}$ See Buisson, Nouveau Dictionnaire de Pédagogie et d'Instruction Primaire, 874-875.

${ }^{15}$ The Universal Exhibition of 1851 in London showed how Britain had fallen behind in economic and technical terms, serving as an incentive to the establishment of higher education institutions. In the Universal Exhibition of Vienna, Austria in 1873, two school floor plans were presented by Fradesso da Silveira, the Portuguese Royal Commissioner, which received an honourable mention.
} 
In the third quarter of the nineteenth century, a new historical and pedagogical cycle emerged, at both central and local levels, associated with the creation, institution, and normalisation of governmental bodies for the regulation of school-related issues. Gradually, this hierarchical complex of official bodies, which used the same type of standard forms and served as a bridge between central government and regional and local entities, all connected by the same bookkeeping procedure, affected education in a broad sense. The school complex had generated a written, organised, multiform, hierarchical bureaucracy with the potential to redefine the social structure. School bureaucracy emerged prior to state bureaucracy, and served as its model. The municipalities, which were duly integrated in and compliant with the bureaucracy of the state, were authorised and called upon to take scholarly initiatives by teaching, acculturating, and drawing new audiences into the public sphere. It was also the duty of the municipalities to foster production and agricultural and industrial trade, leading to the internationalisation of products and measures. In the education of adults and professional training, municipal authority was, in some circumstances, vital to the functioning of the economy, local and regional administration, and justice. The municipalities ensured a census of school-age children was conducted, as well as an inventory and characterisation of socially and culturally deprived populations. Towards the end of the nineteenth century, the plan for schooling was entrusted to governments and municipal organisations in the vast majority of states.

The standardised reforms of the late nineteenth century, which brought together the political regime and school education, in which historiography highlights the policy of Jules Ferry, in the French Third Republic, were based on the territorialisation entrusted to the municipalities' regimentation. The municipalisation of schooling became associated with the new methods of governing education and schooling, and went on to become a definitive part of the educational systems. Formation of the British schooling system was based on municipalisation. In most of Europe, a number of municipalities sponsored pedagogical innovation, and these experiences became recognised by the new school conventional framework. In the map of Adolphe Ferrière, published in Let Us Change School, the pedagogical experiences of private, free, and municipal schools may be encountered. ${ }^{16}$ The core of school education, composed of a curriculum and a pragmatics of national writings, found its accomplishment at the local level, where experiences such as free education and work-oriented schools had been made possible. The pragmatics of schooling had fundamentally stemmed from formal writing, from the pedagogical and sociological on a local scale while the institutional was a product of the standardisation of the teaching profession. However, as a social project, based on the humanity and perfectibility of the human person, it was transferrable to other territories and different political regimes. ${ }^{17}$ Hierarchically and curricularly progressive, the school institution was adjustable to territorial, organisational, administrative, economic, and cultural cartographies, serving the municipalities in the progress and well-being of their populations. By planning and programming education, welcoming the school institution,

\footnotetext{
${ }^{16}$ See Adolphe Ferrière, Transformemos a Escola. Apêlo aos Pais e às Autoridades [Let's transform the school. Appeal to parents and authorities], trans. A. Viana de Lemos and J. Ferreira da Costa, Preface by António Sérgio (Paris: Livraria Francesa e Estrangeira Truchy-Leroy, 1928).

${ }^{17}$ António Sérgio wrote the Preface to Ferrière's Transformemos a Escola. Apêlo aos Pais e às Autoridades and put it into circulation. During his short term as minister for education (1923-4), launched a plan to municipalise primary education. He proved to be a defender of the work-oriented school and, inspired by the experience of collective municipal participation and governing, idealised the municipal school as a place of self-government for humanistic, scientific, and civic education.
} 
and bestowing meaning upon school education and sociability, the municipalities established themselves as pedagogical municipalities.

In the first decades of the twentieth century, the municipal topos and ethos continued to inspire educational and school innovation. Indeed, the self-government, the school money box, the civil court, and the suitability of professional training to the local economies, remained connected to the civic and identity experience of municipalism. Municipal ethos underpinned the British local education authority, established by law in 1902. The historical pedagogical regimentation cycle, characterised by the intrinsic association between school educability and the political regime (evolving in the same direction and giving rise to intellective, performative, and mobilising idiosyncrasies) strengthened, rather than destroyed, municipalisation. ${ }^{18}$ Regimentation became extensive to the republican and socialist regimes, and also later to the integralism and corporatism of the state. Marking the transition of the nineteenth century and extending up to the post-First World War period, regimentation accompanied the internationalisation of schooling through pedagogical, human, and social sciences.

The statistical comparison between models and nations, based on numerical indicators and developed throughout the second half of the nineteenth century, evolved on the basis of a comparison of experiences focused on the nation states, for the convention and transnationalisation of the school model. This was the icon of the new school. This evolution continued throughout the period between the two world wars, coinciding with a broadening of the national education systems through the conversion of the school into comprehensive and universal globalisation. The historical and pedagogical comprehension-universalisation cycle, marked by the aim of drawing as many pupils as possible for the maximum amount of years into the school system, with specific reference to the British Education Act, was, as already mentioned, welcomed and supported by UNESCO and the great international confederations, such as the OECD, under the icon of equality, democratisation, and development. In the late 1960s, school standardisation and internationalisation entered a crisis, and the following decades were marked by tension between internationalisation and globalisation and diversification and localisation. Therefore, it may be accepted that a new historical and pedagogical cycle emerged from the diversification of the late 1970s. Thus, the municipalities recovered a new sovereignty to counterweight the global, namely identity and mobilisation towards integrated development.

Although the municipalities transported common and contrastive characteristics, while also benefiting from such an evolution in the educational sphere, they were, themselves, a part of this historical evolution. Despite the main consequence of this sequence of historical and pedagogical cycles having resulted in the implementation of a common school policy, there was room for difference, uniqueness, acknowledgement of the contrast between urban and rural worlds, and the suitability of the economies and socio-culture at the local level.

\section{Memory and reconstruction of the municipalities in education}

Nation states have been the focus of historiography. However, local and regional entities have continuously participated in written acculturation and schooling. Since the second

\footnotetext{
${ }^{18}$ See Justino Magalhães, Da Cadeira ao Banco: Escola e Modernização (Séculos XVIII-XX) [From the desk to the bank: school and modernisation (18th-20th centuries)] (Lisbon: Educa \& Ui\&dCE, 2010).
} 
half of the eighteenth century, namely in Spain and Portugal, general questionnaires and inquiries had been implemented to gain knowledge, a description, and characterisation of the locations. These inquiries included features such as the population, natural resources, production, constructed heritage, and specialised officials. Indirectly, these inventories provide information on school institutions and schoolmasters. In the mid-nineteenth century, the development of statistics to support decision-making was reflected in general inquiries and consultations, in addition to a population census. In these inventories, as in the inquiries, information on school institutions, schoolmasters, teachers, and populations are grouped into provinces and provincial centres, itemising colleges, schools, and study centres. Pupils are grouped by gender and level of schooling. Obtaining information and the historiographical reconstruction of the territorial unit is consequently an indirect exercise, with the application of a reconstructive method. This difficulty became more attenuated with the liberal reforms, in view of which populations and central government regarded the establishment of the municipality as a representation of local issues.

As already mentioned, in Portugal, counties have been referred to in the documentation on education since the second half of the eighteenth century. In order to reconstruct the school supply by county, it is also necessary to use complementary historical documents: national, which need to be detached in order to reconstruct the local sphere; and local documents which, having supported the former, were forgotten during the period of national standardisation. In order to construct the historical and pedagogical framework of state control, there are general maps that are part of the Pombal administration and Queen Maria I reforms from city hall documentation, held in the municipal archives, namely Livros de Vereação e Livros de Registo de Privilégios e Mercês. There is also specific information collected in the Folhas de Pagamento aos Professores. ${ }^{19}$ The Royal Charter of 31 January 1800 contains the Lista dos Mestres actuaes de Primeiras Letras na Corte e Província da Estremadura cujas Contas de Officio forão remetidas. ${ }^{20}$ Established by the Liberals, the Conselho Superior de Instrução conducted the Consultas gerais.

In the case of Spain, the Constitution of 1812 (Cadiz Constitution) acknowledged the Ayuntamento, maintaining the municipalities of the former regime and extending the denomination without distinguishing "royal municipalities" from "lordship municipalities". A standardisation process was already under way, establishing locations with 1000 inhabitants as "municipios de ayuntamento". Once the Spanish Liberals had regained power in 1820, a decree was approved on 29 June 1821, the General Regulation of State Education, which

\footnotetext{
${ }^{19}$ These are the main national maps. The map proposed by the Real Mesa Censória (Charter of 6 November 1772) - Mapa dos Professores e Mestres das Escolas Menores e das Terras em que se acham estabelecidas as suas Aulas e Escolas neste Reino de Portugal e seus Domínios [Map of the teachers and masters of the minor schools and lands in which their classes and schools are established in this kingdom of Portugal and its domains], expanded by the 1773 Map (Charter of 11 November 1773) - Suplemento ao Mapa dos Professores e Mestres das Escolas Menores [Map of the teachers and masters of the minor schools], providing a more detailed vision of the municipality framework. The Law of 16 August 1779 includes the Lista das terras, conventos e pessoas destinadas para professores de Filosofia Racional, Retórica, Língua Grega, Gramática Latina, Desenho, Mestres de Ler, Escrever e Contar (F) por resolução Real de Sua Majestade de 16 de Agosto (F) de 1779, tomada em consulta da Real Mesa Censória de 12 de Janeiro de 1778 [List of lands, convents and persons destined for teachers of rational philosophy, rhetoric, Greek language, Latin grammar, drawing, masters of reading, writing and counting (F) by Royal Resolution of His Majesty of August 16, 1779, Taken in consultation of the Real Mesa Censoria of January 12, 1778] [National Library of Portugal, Res. PBA 462]. Information on the supply of schools may be complemented with information collected from the teachers' payrolls. The Consultas da Real Mesa Censória [Consultations of the Real Mesa Censória] and Consultas da Directoria Geral dos Estudos [Consultations of the General Directorate for Studies] also fall within a national scope.

${ }^{20}$ Biblioteca Nacional de Portugal (BNP) [National Library of Portugal], Res., Mss. 1, no. 12.
} 
created the directorate general for studies. As a result, "el proyecto de regulamento general de primera enseñanza, de 1822, estabelecia todo un sistema de información estadística periódica a partir de los mismos municípios y escuelas". ${ }^{21}$ A municipal committee was then to be established in order to communicate with the schoolmaster. However, with the return of the absolutist regime, this process was suspended.

The integration of municipalities in the history of education includes designation, cartography, and statistics constituting and constructing the municipality as an observation unit and a historiographical object. This historiographical reconstruction was obtained through a database. The emergence of statistics at the end of the eighteenth century, resulting in a combination of geometry and accounting, as a synchronous representation of space and time, regarded the municipality as a topographical unit and a product of a social and natural action. The educational municipality contained territory, government (county), and identity and was part of a written acculturation process. While it is an epistemic reality, as has been demonstrated, the history of European municipalities is largely incomplete. In the Pombal administration schooling plans, the Portuguese municipalities were referred to as administrative entities and educational locations.

Territorial, demographic, and administrative reconfiguration and the establishment of a hierarchy were aspects that irreversibly determined the history of municipalities and of municipalism, given their economic autonomy and projection of development. In fact, by putting the principle of "creating larger municipal counties" into action, in order to prevent existing counties from becoming "very poor" and to enable new counties to obtain more funds, by order of Decree of 6 November 1836, 498 counties were extinguished and 21 new counties were established. The total number of Portuguese municipalities was set at 382 . The 826 counties that had existed in the late eighteenth century were reduced by around $60 \%$ by applying the criteria stipulated in the successive Liberal Administrative Codes. This territorial and administrative reordering was underpinned by criteria based on functionality in addition to a projective rationality. This rationale consisted of a coefficient related to the potential of development, in view of which, during the second half of the nineteenth century, the municipalities became hierarchised, eliminated, or replaced. ${ }^{22}$

The action of the county was recorded through municipal writing. Municipalities had served as a local representation since the Pombal administration reforms. Indeed, after the liberal reforms, municipalities ceased to be merely a representation and were also decision-makers. State education issues were included in municipal bookkeeping. It is this informed and sovereign status of the municipality that the Educational Atlas of Municipalities in Portugal (1750-1986) ${ }^{23}$ sought to record and which is summarised in this article. It is a systematic record of information, organised into five historical and pedagogical tables on the basis of municipality, which includes features such as the school network. The formula and content of the Atlas cover a joint, comprehensive, descriptive, and evolving plan. This

\footnotetext{
${ }^{211}$ The draft general regulation of first education, of 1822, established a system of periodic statistical information from the same municipalities and schools," in Guereña e Viñao-Frago, Estadística Escolar, 79 (map).

${ }^{22}$ In the Atlas-Repertório, a statistical study was conducted in order to determine the coefficient of development underlying the allocation of funds to schooling. See Gilda Soromenho, "Contributos à compreensão da distribuição de verbas destinadas à educação nos municípios portugueses em 1870-1880" [Contributions to the understanding of the distribution of funds for education in the Portuguese municipalities in 1870-1880], Interacções 10, no. 28 (2014): 31-9, http://www. eses.pt/interaccoes.

${ }^{23}$ Justino Magalhães, Do Portugal das Luzes ao Portugal Democrático. Atlas-Repertório dos Municípios na Educação [From the Portugal of the Enlightment to democratic Portugal. Atlas-Index of municipalities regarding education]. Lisbon: Universidade de Lisboa/ Instituto de Educação, 2014. Ebook, http://hdl.handle.net/10451/18286.
} 
historiographical work includes a theorisation that encompasses designation, factor variation, causality, and the search for meaning throughout the long duration of municipalism and its specific context. The pedagogical municipality is an operative and meta-historical concept. The historical sense is reflected in an educational municipalism, circumscribed by time frames and organised into a series of historical and pedagogical frameworks.

In order to draw up this Atlas-Repertório, a reconstructive method was implemented in which the municipality was constituted as a composite, qualitative, and quantitative variable. At a qualitative level, the municipality corresponded to sovereignty in its geographical configuration, curriculum typology, and in terms of inspection. From a quantitative stance, the supply of schooling, compliance, territoriality, and the total and school population were dependent on it. A digital, interactive, and expansive database was created with three recording units: the county, the school unit, and a culture unit. Each recording unit consisted of duly divided and explained variables, which were allusive and articulated, thus permitting different types of analysis and estimation. The variables were numerical, informative, and qualifying (scales). A cross-analysis of these variables, according to the exploration models or new trials, made it possible to calculate the critical and prospective coefficients.

Taking written acculturation as the theme, and focusing research on the relationship between school and society and on the state-municipality binomial, the municipality emerges in possession of its own ideology and ability to make political and pedagogical decisions. The pedagogical municipality was the territorial unit for cartography and schoolrelated statistics. It was also the reason behind the pedagogical adjustment of language and national culture to regional and local realities. This educational history of municipalities and municipalism was based on a representative and significant archive, which collected and crossed information from local and national archives. For each municipality, it was necessary to catalogue, record, and process indirectly collected information on documentation common to the government and to the memory of the county. This cumulative database was a heuristic support, organised on the basis of time and filtered by the criteria of the conceptual and theoretical framework. Mapping provides a new vision of the descriptive sequence and a more effective representation of the space-time combination. Local-scale education is a historiographical construction, with a life of its own. Historically, the municipalities were an alternative, a complement and subsidiary to the central supply of schooling. Historiography developed in this manner recovers the cartography of municipal schooling and the reinvention of the nation state school map.

\section{Historical and geographical atlas of the Portuguese municipalities (1750- 1986)}

By aligning municipal perspectives, transversal to the different historical periods, one may infer that up to the 1940s, the intervention of the Portuguese municipality, in terms of education, was progressive and, in its own way, cumulative and autonomous. State control applied a plan to municipalities that was defined at a central level. During the transition to the liberal regime, and within the context of school nationalisation and the standardisation of school culture, the municipalities were frequently consulted, through general questionnaires sent by government appointees, and later by civil governors. Following the liberal reforms and regeneration, and within the context of a constitution of the school governing system, municipalities acted with sovereignty and the ability to project decisions. The 
action of municipalities spiralled according to each historical and pedagogical cycle. Some of the municipalities' responsibilities involved: establishing and maintaining municipal government bodies for education-related matters; creating a plan to improve and broaden the school network; intervening in the hiring process of teachers; creating courses for adult literacy and vocational or professional training; establishing school supplementarity; sovereignty in the educational and developmental ideology continued to be reflected in the Posturas; and the regulation of public spaces. As a result of these historical and pedagogical cycles, some features of municipalism have been maintained, regardless of the political regime changes in Portugal. The municipalities played a key role in the supply, universalisation, and expansion of schooling: they bestowed meaning upon education and training; they ensured congruence between nationalism and diversity.

The sequence of maps presented herein corresponds to the evolution of the historical and pedagogical cycles, and focuses on the municipalities as an observation unit and the total number of schools as the variable. The maps have been drawn up with recourse to historical databases in combination with the Geographic Information System (GIS). They are historical and geographical maps that present the total number of schools, adjusting this total to the variation of the territory of each municipality. The main aim has been to ensure that the cartographic visualisation accentuates the most remarkable aspects of each historical and pedagogical cycle. The same scale has not been used for all the maps intentionally. Trials were conducted to find the most suitable scale for each map. Not only did the global and municipal quantitative indicators vary from one map to another, but also differences were encountered between their distribution and relationship. The map-by-map search for the best scale made it possible to overcome a narrow historicism and to approximate a representative causality of the historical and pedagogical context under study.

\section{Polarised development and the municipality}

The state-controlled cycle stretched across the following periods, reaching its peak at the time of Pombal's administration and the reign of King John VI (1750-1801). It is characterised by the fact that the state took control of schooling, converting primary and grammar schools into state education. Municipalities were constituted as poles of development, bringing together the demographic element and the geographical situation; asserting themselves as centres designed to serve different places; presenting a certain degree of urbanism; and holding a legal-administrative status. During the process of state control, the municipality established the local sphere. Although the reign of King John VI surpassed the liberal revolution, the first 20 years of the nineteenth century correspond to a significant advance of municipalism, which is why these changes are deemed to have triggered the subsequent period.

During this period, 1518 schools were accounted for, including primary and grammar schools (Figure 1). Only 1482 units of education were calculated for differentiation and territorialisation, since information was only found for these and not all the schools. The primary school map shows that the overall school network was extensive to the entire country and that, overall, there was a basic supply of primary schools. There was at least one school unit per county. However, in some cases, this minimum extended to a vast area. The main distinction was in the contrast between Portugal north of the Tagus and 


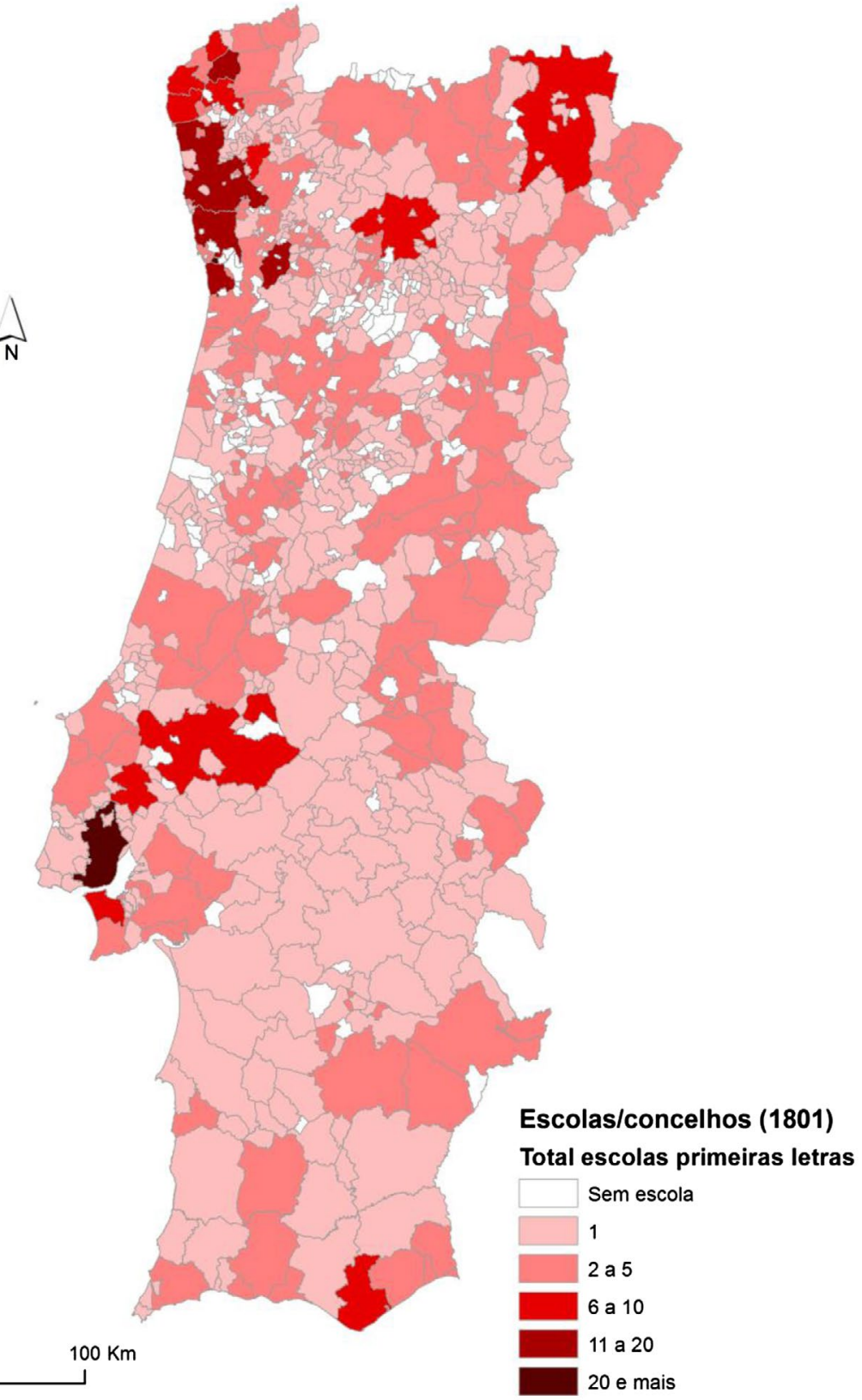

Figure 1. Total primary school map and grammar school map (1801) Legend: schools/counties (1801) total no. of primary schools/1 / 2-5 / 6-10 / 11-20 / 20+. @ Institute of Education, University of Lisbon.

Portugal south of the Tagus. There was a higher prevalence of schools in the north Atlantic and north hinterland regions (particularly in Braga and Bragança, and in the meso-region surrounding Vila Real). The regions north of the Tagus, namely the meso-region of Lisbon and the Santarém region also presented a higher density of schools. South of the Douro, an 
accentuated line of density could be observed which extended to the Beirão hinterland. The network of non-state schoolmasters and schools reinforced the network of royal schools, and in a large part of the territory they would frequently overlap.

The royal network of grammar schools was more polarised than the network of primary schools. The supply of schools was concentrated around the main cities. Once again, this school supply was more prevalent in the regions of the north Atlantic and the north hinterland. Lisbon and Bragança recorded the highest density. The network of royal elementary schools shows that there was a line of schools along the southern Douro River towards the hinterland. Conversely, there were adjacent regions with no grammar schools. The network of private grammar schools was associated with the main hinterland cities.

The school network was largely broken down into administrative divisions. Of the 804 counties referred to as the main primary or grammar school poles, 481 (corresponding to $59.82 \%$ ) belonged to the set of Beira and Minho provinces.

\section{The municipality as constitutive of national schooling}

The meaning that unites liberalism and regeneration (1802-1878) is rooted in the coordination between the expanding school supply, curriculum nationalisation and standardisation, and a redefinition of the school network by municipalities. School municipalisation was a means of strengthening local communities by integrating the prerogative of development and the right to self-sufficiency, as may be observed by the successive redefinitions of the municipality network. The municipal entity brought together an organisational and economic structure which was not only self-sufficient but also contributed to the state (a legal and administrative centre, political, educational, and cultural centre - school, library). With regeneration, the municipality progressively asserted itself as a centre of progress.

The municipality was at the root of the nationalisation of educational schooling. In view of the new administrative structures, such as civil governments, which were legitimised at an external level, the municipality re-founded its county internality. An opposition emerged between organisation and institution, born from territory, municipal identity, tradition, and customs. A significant number of these measures were in response to the inspection inquiries, namely those of 1875 which gave rise to a critical assessment and adjustment of the county plans.

The network of primary schools was extended throughout the nineteenth century. Taking 1878 as the year of observation, to which the map below refers, it was concluded that practically all the counties had more than one primary school (Figure 2). However, it was not possible to find data relative to the county of Fundão. This analysis highlights the contrast between Portugal north and south of the Tagus, in line with the conclusion observed for the aforementioned historical and pedagogical cycle. This contrast tended to become more acute, particularly in the north and south regions of the Central Mountain Range. This asymmetry dates back to the former regime; however, during the nineteenth century, significant changes were observed, namely in the hinterland region of Beira and in the main school centres.

The municipality of Lisbon had 36 schools and there was a considerable number of counties with over 17 schools. Such was the case of the Brigantino counties (Bragança and adjoining counties as far as Chaves) and, further south, of Vila Real, Amarante, Paredes, and Penafiel. The set of counties forming the border axis of Guarda is also included in 


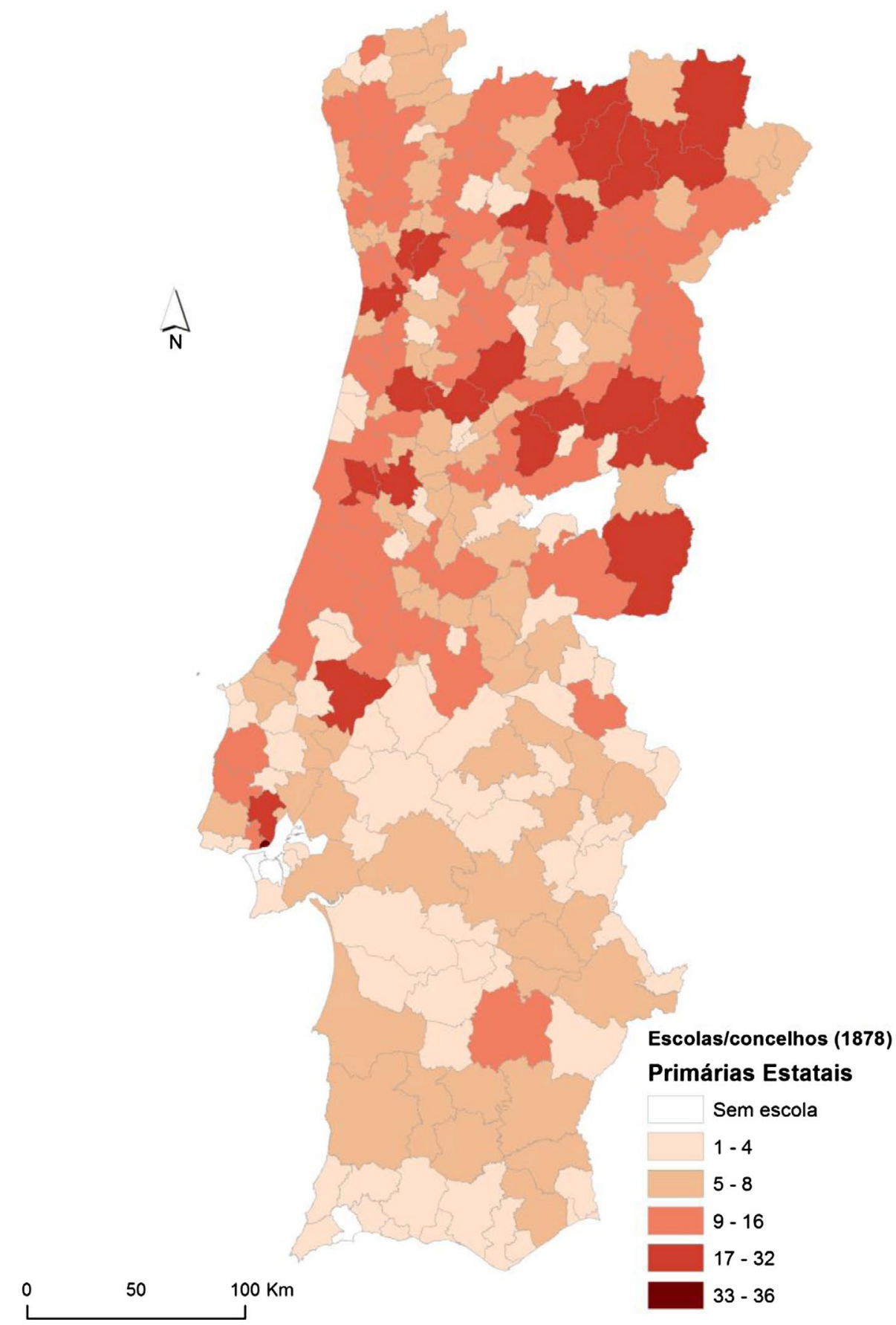

Figure 2. Map of state primary schools (1878) Legend: schools/counties (1878) total no. of state primary schools / 1-4 / 5-8 /9-16 / 17-32 / 33-36. @ Institute of Education, University of Lisbon.

this stretch, namely Seia, Gouveia, and Sabugal. Further south, there was Idanha-a-Nova. Some urban and peri-urban areas also fit into this stretch, such as Viseu and its limits, Coimbra, Montemor-o-Velho, and Porto. The counties of Vila da Feira and Santarém were also included in this stretch. This mesh of counties with a density of between 9 and 16 schools 
extended beyond the periphery of the aforementioned centres, spreading and connecting them on a broad scale. This patch of schools supported the former, and covered the main terrestrial itineraries. By joining these two stretches, areas of contiguity may be observed leading to strands of development.

There were regional and sub-regional areas that presented an average in the region of 20 schools. In many of these cases, an improvement may be observed in relation to the previous period which was partly the result of passive acquisitions, obtained through a merger of counties, but also from the expansionary policy of the school network. These large cartographic stretches were an irreversible sign of the process of transformation in Portugal. The Portugal of the nineteenth century presented a school network in which the coastal areas began to assert themselves, while the territory south of the Tagus only slowly began to be covered with schools. Thus, the potential for development was clearly observed to be intrinsically linked to the budget for education. Furthermore, within this budget, the rate of schooling was determinant; in other words, the higher the school population the greater the investment, and this investment corresponded to a higher demand for schools.

\section{Republicanism and pedagogical municipality}

The autonomous sense of the pedagogical municipality, within the scope of republicanism (1878-1932), corresponds to an accentuation of the polarisation and supplementariness of schools, to the benefit of the municipal alternative. The republican municipality, based on a pedagogical municipality organisation, became the driving force behind regionalism and federalism as a replacement of central government. Despite the interruption of the republic in 1926, the role of the municipalities continued throughout the military dictatorship. One of the main lines of development of republicanism was the municipal confederation, in which there was a convergence of the municipal alternative and supplement and polarisation. Municipalism became the driving force behind regionalism and federalism (supplement of central power); the educational reforms became associated with the municipal reform.

Within the overall calculation of this historical and pedagogical framework, taking 1931 as the year of reference, 7657 primary schools were accounted for (Figure 3). Of these, 7206 were state schools. A significant density of schools was maintained in the northern hinterland and central regions of the country, particularly in the counties of Viseu and Guarda, which were the capital counties of the district. Urbanism had gradually become a factor of positive discrimination. The capital counties presented greater vitality. Guarda and Vila Real had more schools, followed by Viseu. However, a set of district county capitals did not present the highest number of schools. Such was the case in Aveiro, Castelo Branco, Évora, Faro, and Porto. This discrepancy is related to the fact that some counties had more territory. There was a large percentage of mixed schools.

The primary schools map shows that while giving justice to the policies that permitted the creation of municipal categories, there were many asymmetries within the same district and from area to area. School development continued to highlight geographical areas and contiguities, but also counties. Some counties, such as Leiria, had double the schools of the county in the background. Contiguities such as Santarém, Torres Novas, and Abrantes have represented a speedy development phenomenon since the late nineteenth century. 


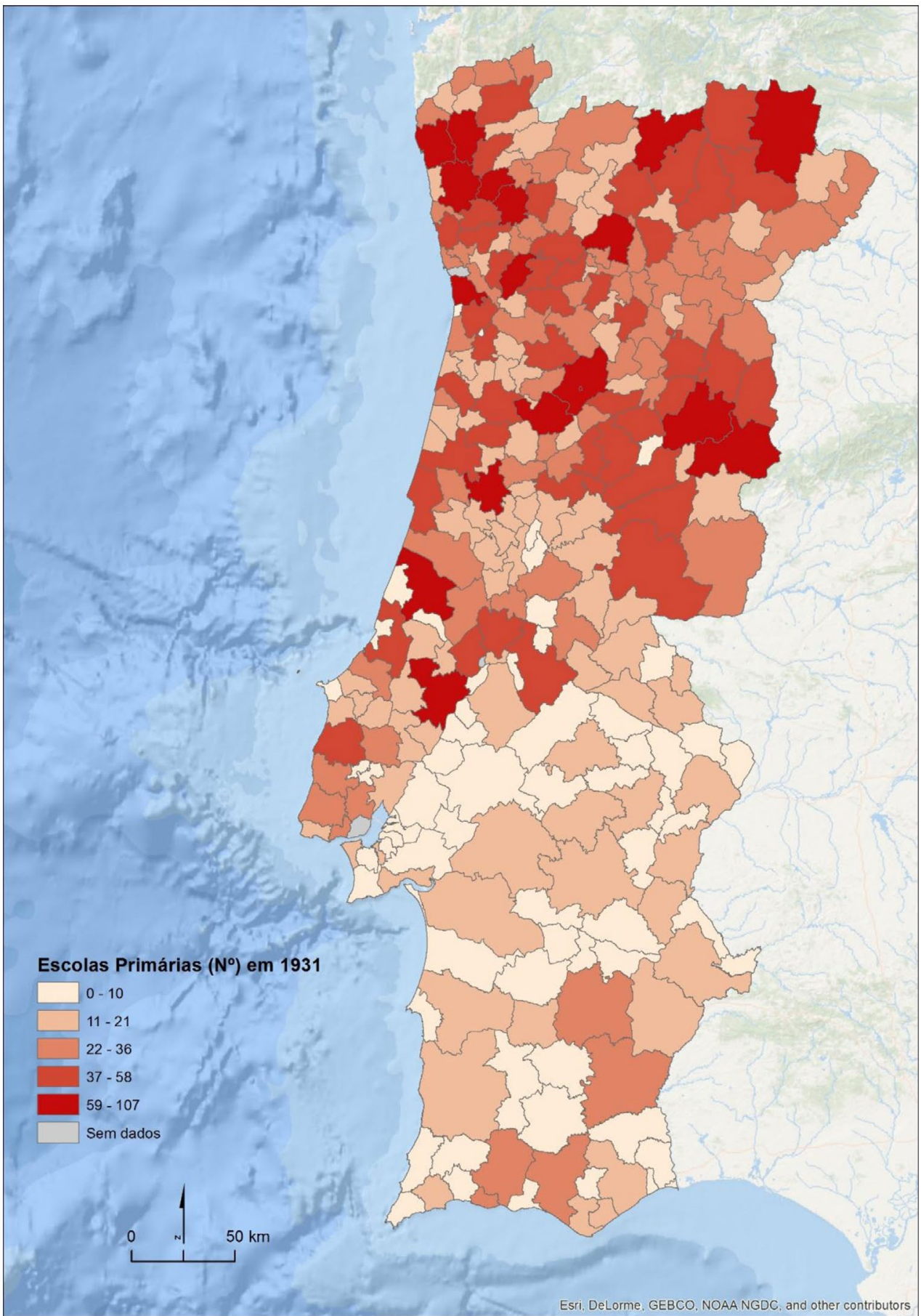

Figure 3. Map of primary schools (1931) Legend: total no. of primary schools (1931) 0-10 / 11-21 / 22-36 / 37-58 / 59-107 / lacking data. @ Institute of Education, University of Lisbon. 


\section{The corporative municipality and school universalisation}

The general principle regarding the participation of municipalities in schooling, under the New State (1933-1974), was the complementariness of the state school supply. However, in the early stages of the New State, in which priority was given to the completion of three years, and later four years of compulsory schooling, obligations in the creation of premises and the preservation of buildings were attributed to the municipalities.

The fostering of literacy was another movement in which the municipalities were involved. They participated in the creation and functioning of courses, and in the promotion of reading through public libraries. A third municipal movement involved bringing together the expansion of schooling and technical and professional training. Within the scope of the technical and commercial educational reform preparations, a lengthy process which lasted several years in the 1940s, city halls took on the representation and problem-solving of all local educational needs.

The presentation of the map with the school network of 1964-65 sets out to mark an arrival point in terms of the supply and organisation of primary education (Figure 4). The schools under the centenary plans had been duly constructed and accounted for, which also corresponded to the incorporation and subsequent suppression of small schools in central buildings, namely through the progressive extinction of school centres. The comparison between the total number of schools in 1940 and 1965 does not indicate an expansion of the network in absolute terms. What is most significant is the relative growth. There was a higher density of schools along the coastal areas, north of the Tagus. The counties of Leiria, Vila Nova de Gaia, Guimarães, and Barcelos had over 200 schools, as was the case with Viseu. A total of 41 counties, generally those on the northern and southern coastal areas of the Douro, were observed to have over 100 but fewer than 200 schools. This highly dense patch proceeded through the Douro valley, drifting towards Bragança in the north east of Trás-os-Montes. Chaves stood out for its high density of schools. South of the Tagus, only the county of Odemira was included in this stretch.

The corporative municipality had been reconfigured as a body of state organisation. It was part of the social, cultural, and pedagogical municipality, however it safeguarded a margin of sovereignty as a supplement and alternative to the state school supply. The extension of compulsory schooling brought new commitments to the municipalities.

\section{The municipality and school diversification}

Following the democratic revolution in 1974, and during the period up to the approval of the Lei de Bases do Sistema Educativo (Basic Law on the Education System) in 1986, the municipalities became autonomous. New challenges to territorialisation and municipal identity began to emerge. This cycle occurred within the scope of mass schooling. The democratic framework favoured local, inter-municipal, and regional autonomisation, even in terms of international relations. Nevertheless, despite their involvement in resolving formal schooling, adult education, and professional or vocational training, the democratic municipalities only effectively accomplished their initiatives some years later. The socio-cultural dynamics and the associative movement dragged the municipalities towards supervision and the funding of various types of initiatives. 


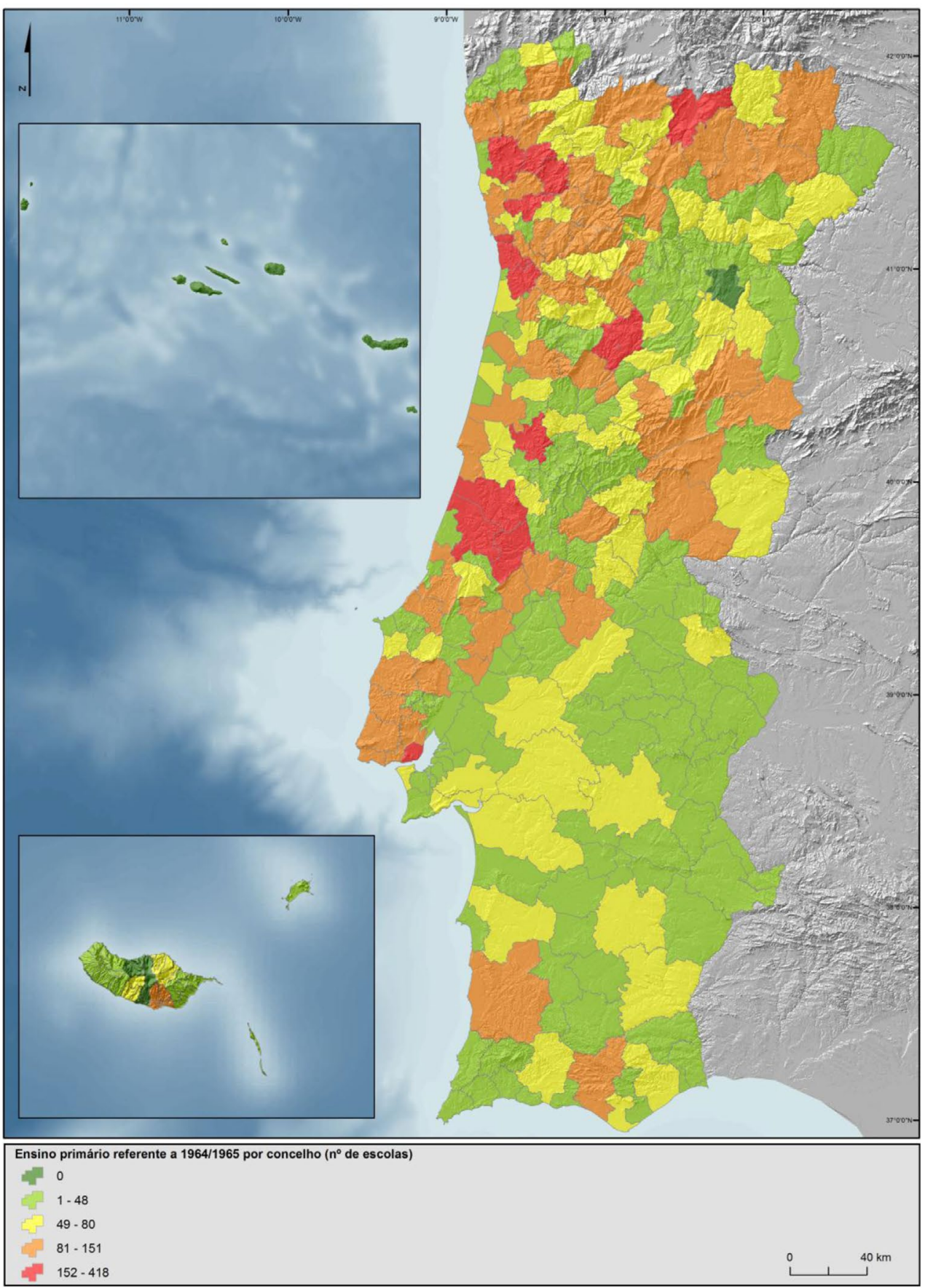

Figure 4. Map of primary schools (1964-65) Legend: primary education relative to $1964 / 1965$ by county (no. of schools) 0 / 1-48 / 49-80 / 81-151 / 152-418. @ Institute of Education, University of Lisbon.

In the 1970s, school expansion was fundamentally a result of the preparatory cycle. Growth in schooling was not consistent, and both the social and regional asymmetries tended to become more accentuated, as shown by the cartographic data of the Atlas. Forced, 
for multiple reasons, to be complementary and, quite frequently, to be supplementary in the performance of compulsory schooling, the municipalities undertook a number of qualitatively and quantitatively differentiated initiatives. At the same time, challenges and duties were brought to light which, within a context of proximity, integration, and education, the municipalities could not afford to underestimate, and regarding which there are no detailed studies. For instance, there are no precise data on: the response to the school population growth (in which infant, youths, and young adults resistant to regular schooling are included); the schooling and cultural supply to new populations, namely immigrants or neo-residents; or the offer of an educational and cultural component to senior citizens.

The primary school map (resulting from a count of 8544 schools) relative to the end of the 1970s, presents a far more irregular patch than the previous map (Figure 5). The quota of up to 28 schools per municipality is the most generalised by the country, representing a progressive concentration of classes in the same school building. The average quota of up to 50 schools per municipality is also rather dispersed in the central and northern regions of Portugal and the coastal area of the Alentejo. Trás-os-Montes and the north Atlantic region as far as Porto, the Coimbra region as far as the Atlantic, the extreme east and, in a more isolated manner, the counties of Guarda, Castelo Branco, Santarém, Abrantes, Odemira, and Loulé continued to present a high density of schools. The counties with over 100 schools were Lisbon and Leiria, followed by Viseu, Bragança, Chaves, Barcelos, Montalegre, Vila Nova de Gaia, Pombal, Ourém, and, a little further south, Vila Real and Guarda. They were the same geographical centres as those indicated in the previous period. In spite of sporadic alterations, the growth tendency of the school network became more and more restrained. ${ }^{24}$

\section{Municipalism and the modernisat ion of schooling}

This overview contains the historiography of municipalism and the history of education. The dialectics among plan, consultation, and autonomy corresponded to a contraposition between the movement based on organisation and complementariness, a product of the state plan, and the municipal movement, stemming from the principle of subsidiariness and the alternative to the supply of state education. Municipalisation had a structural motive, namely the pedagogical municipality, which, when analysed with the evolution of Portuguese society, makes it possible to systematise the narrative composed by this historical and pedagogical sequence.

With the political transformations that marked the former regime, the municipalities, denominated according to their topology and status, assumed representation, formalising and pursuing the vindications of the local populations towards the central government. With the dissemination of liberal ideologies, they favoured and accomplished citizenship, and undertook the obligation to foster literacy associated with administrative modernisation. This duty/obligation developed into a polarisation of sovereignties and decision-making powers, through which strategies and autonomous ideologies were consolidated. Within the corporative scope of the state, the municipality, a corporative entity itself, was required

\footnotetext{
${ }^{24}$ See Justino Magalhães, "Municipalização do ensino em Portugal. As lições da história [Municipalization of teaching in Portugal. The lessons of history]," in Professores, Escola e Município - Formar, Conhecer e Desenvolver [Teachers, school and municipality - training, knowledge and development], ed. Joaquim Machado and José Matias Alves (Porto: Universidade Católica Editora, 2015), 127-41, http://www.uceditora.ucp.pt/site/custom/template/ucptpl_uce. asp?SSPAGEID=3005\&lang=1\&artigolD=1557.
} 

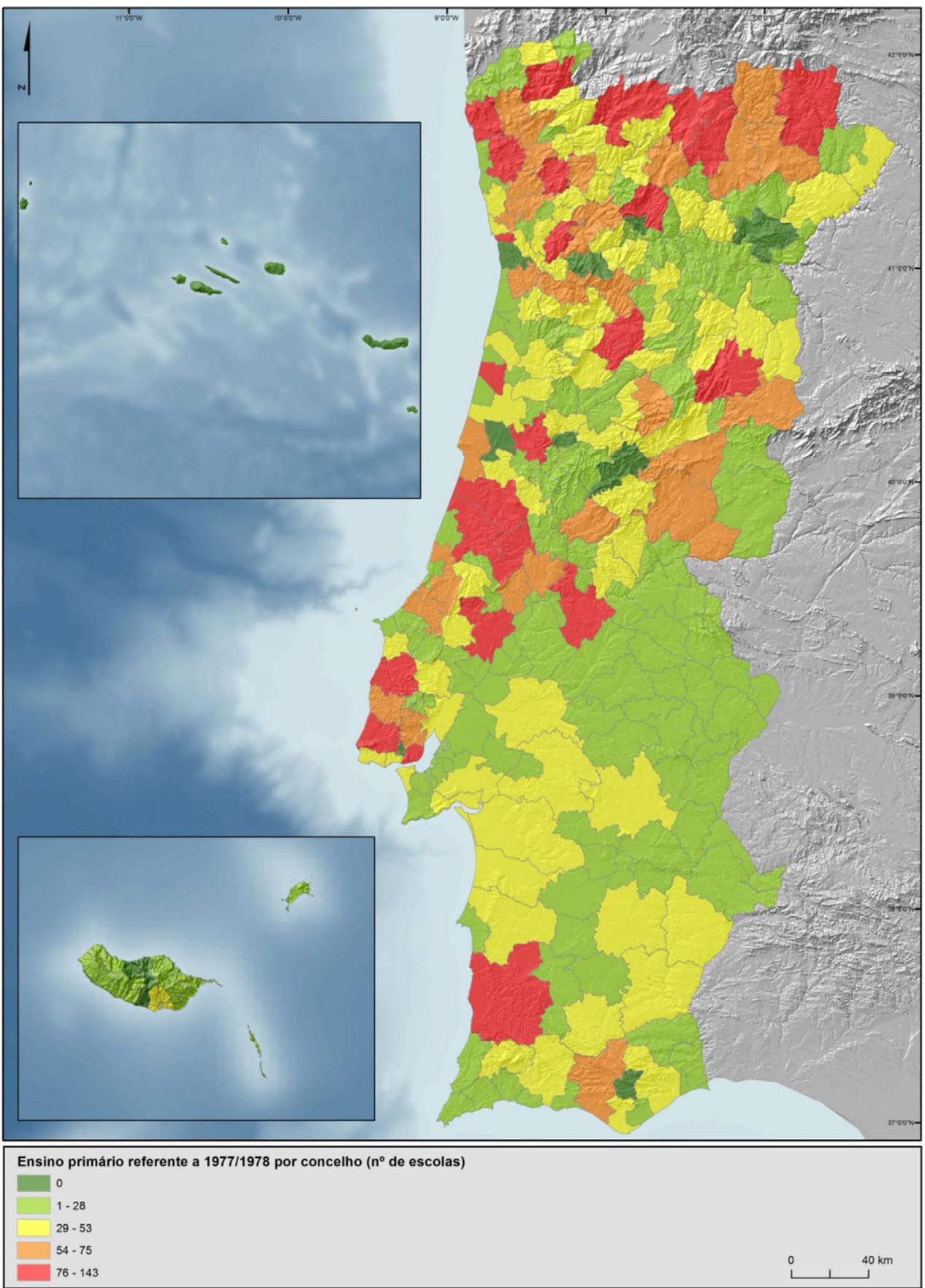

Figure 5. Map of primary schools (1977-78) Legend: primary education relative to $1977 / 1978$ by county (no. of schools) 0 / 1-28 / 29-53 / 54-75 / 76-143. @ Institute of Education, University of Lisbon.

to foster hierarchical integration, thus constituting a structuring nation cell, and securing complementary duties. With the democratic revolution, Portuguese municipalities were entrusted with new competencies in terms of education and culture, namely the organisation 
and guarantee of transport for primary school pupils; socio-community education; preschool education; and the protection of senior citizens.

The historiographical observation and cartography of each municipality within the field of education, namely the supply of schooling, precisely as it was systematised, unveils a history with intermittences. However, it is possible to infer, reconstitute, and describe a long duration of municipalism. The intermittency of the municipalities within the national framework is also relative to autonomies and internationalisation movements. In the context of nineteenth-century regeneration and reform, municipalism served as a complement and an internalisation. However, with the universalisation of the school model, between the mid-century and the crisis in the late 1960s, the municipalities were responsible for the expansion of and compliance with compulsory schooling; they were branches of the state system for new populations and new school and cultural challenges. At the financial and logistical levels, as also in terms of materiality, sociability, and urbanism, the educational municipality reified and granted authenticity to education, in comparison to the virtuality of the global.

The matter, organicity, and services granted to the municipalities since modern Europe may also be observed. Some matters, although not directly attributed to the municipalities, represented the tradition and continuity of municipal practices. They created devices to suppress needs that were not intrinsic. They were a logistical and technical reserve in periods of breakdown and radical change in the functioning of services and central bodies. Throughout this long duration, a continuity that bestowed a historical identity upon the educational municipality may be observed; in an integral, sequential, and forward-looking manner, the municipality capitalised on opportunities and circumstances to transform itself and evolve. This is what happened in the fields of education, training, and schooling. The pedagogical municipality, as a meta-history and transformative complex, was on the horizon. Municipal documentation and memory may, perhaps, be scarce, but history shows that at local regional and international levels, the Portuguese municipalities were in harmony with the new guidelines and approaches.

\section{Disclosure statement}

No potential conflict of interest was reported by the author.

\section{Funding}

This work was supported by Fundação para a Ciência e a Tecnologia (FCT) [grant number PTDC/ CPE-CED/116938/2010].

\section{Notes on contributor}

Justino Magalhães is a historian of education and professor at the Institute of Education, University of Lisbon, where he is coordinator of the research and teaching of the history and psychology of education and the doctoral course in the history of education. Research areas and publications include works on: the history of education and schooling; the history of literacy; the history of textbooks; the history of educational institutions; and the history of local and pedagogical municipality. 